\title{
MINDFULNESS AND FIVE FACTOR PERSONALITYTRAITS AS PREDICTORS OF HUMOR
}

\author{
Zümra ÖZYEŞIL ${ }^{1}$, M. Engin DENIZ², Sahin KESICI ${ }^{3}$
}

${ }^{1}$ Istanbul Arel University, Faculty of Letters and Sciences, Department of Psychology Turkoba Mah. Erguvan Sok. No: 26/K Tepekent - Büyükçekmece, Istanbul, Turkey

E-mail: zumraozyesil@arel.edu.tr

${ }^{2}$ Faculty of Educational Sciences, Department of Psychological Counseling and Guidance Yildiz Technical University

E-mail: edeniz@yildiz.edu.tr

${ }^{3}$ Faculty of Education, Department of Educational Sciences

Psychological Counseling and Guidance Program

Konya University Ahmet Keleşoğlu

E-mail: sahinkesici@selcuk.edu.tr

\begin{abstract}
The study aims to determine if mindfulness and the Five Factor Personality Traits significantly predict humor styles. The participants of the study were a total of 502 undergraduate students, 300 (59.8\%) female and 202 (40.2\%) male. Humor Styles Questionnaire (HSQ), Adjective Based Personality Test (ABPT) and The Mindful Attention Awareness Scale (MAAS) were used in order to collect the data of the study. Pearson's Product Moments correlation technique and multiple regression analysis were employed for statistical analysis. The findings of the study show that mindfulness and the Five Factor Personality Traits significantly predict the subdimensions of humor styles.
\end{abstract}

Key words: mindfulness, personality, humor styles

\section{INTRODUCTION}

Webster's Dictionary (1993) defines humor with a meaning that is most modern and relevant for the present purposes as a quality in a happening, an action, a situation, or an expression of ideas which appeals to a sense of the ludicrous or absurdly incongruous; comic or amusing quality; the mental faculty of discovering, expressing, or appreciating ludicrous or absurdly incongruous elements in ideas, situations, happenings, or acts; droll imagination or its expression; the act of or effort at being humorous; something (as an action, saying, or writing) that is or is designed to be humorous. Humor has two aspects, one is understanding and appreciation of humor and the other is the creation and performance of humor (Nilsen, Nilsen, 2000). Humor involves cognitive, emotional, behavioral, psycho-physiological, and social aspects elements and may be a state (amusement, cheerfulness, exhilaration), or a trait (sense of humor). Humor may refer to characteristics of a stimulus (e.g., a comedy film) to cognitive processes (e.g., perception or creation of amusing incongruities) involved in creating, perceiving and understanding and appreciating humor or to the responses

DOI: $10.21909 / \mathrm{sp} .2013 .01 .619$ 
(e.g., laughter, exhilaration) of the individual (Martin, 2001; 2003).

Humor has become an umbrella term and sense of humor refers to humor as a personality trait, sense of humor may be conceptualized as a habitual behavioral pattern, a cognitive ability, an attitude, an aesthetic response, a world view, a coping strategy or defense mechanism (Martin, 2003; Martin et al., 2003). Sense of humor has been recognized as an important adaptive mechanism and is a multidimensional construct, intimately connected with people's well-being (Jose et al., 2007).

A person with a humorous attitude is someone who understands the insufficiencies and shortcomings of life and fellow humans but also tolerates and forgives them rather than pokes fun at them. "Humorless" is the person who dwells on the insufficiencies of existence and weaknesses of fellow humans. Taking oneself too seriously and not being able to laugh at or distance oneself from one's problems are further indicators of humorlessness (Ruch, Carrell, 1998). Humorous person is also seen as having much lower levels of neuroticism and other socially undesirable attributes than the average person. Being humorous is usually thought of as a very positive and desirable personality attribute in others and has a positive impact on our impressions of these individuals (Kuiper, Leite, 2010).

Humor has been conceptualized in a variety of different ways. It is also seen as a personality trait (Martin, 2001) which has been defined as a dynamic organization inside a person and a characteristic pattern of thought, emotion and behavior, making a person different or similar to others (Carver, Scheier, 2000; Funder, 1997; ChamorroPremuzic, 2008). The Five Factor model pro- posed by Costa and McCrae $(1985,1992)$ is a trait theory of personality which posits that there are five major and universal factors of personality also known as The Big Five; Neuroticism, Extraversion, Openness, Agreeableness and Conscientiousness). Neuroticism assesses adjustment vs. emotional instability and is defined as eventemperedness with negative emotionality such as feeling depressed, anxious, nervous, insecure, sad and tense. In addition, neurotic individuals are prone to maladaptive coping responses. Individuals who have a high level of neuroticism are more likely to experience stress in daily life than those who have a low level of neuroticism. The primary facets of neuroticism are anxiety, hostility, depression, self-consciousness, impulsiveness and vulnerability. Extraversion refers to high activity, assertiveness, intensity of interpersonal interaction and capacity for joy. Conversely, low extraversion or introversion is characterized by quiet, reserved, sober, task-oriented and withdrawn behavioral patterns. Openness to Experience assesses willingness to be receptive to new ideas and approaches, a tendency to engage in intellectual activities and experience new sensations and ideas. Openness is associated with tolerance, intellectual curiosity, emotional sensitivity and multidimensional thinking. Agreeableness assesses the quality of one's interpersonal orientation along a continuum from compassion to antagonism in thoughts, feelings and actions. Agreeable people can be described as caring, friendly, straightforward, co-operative, modest and warm. Lastly, Conscientiousness is associated with responsibility, self-discipline and motivation in goal directed behavior. Conscientious people are best identified for their productivity, determination and efficiency 
(Chamorro-Premuzic, 2008; Cooper, 2002; Pervin, 1993; McCrae, Costa, 1987; Burger, 2006; McCrae, John, 1992; Shaver, Brennan, 1992).

Sense of humor is an important characteristic of personality and it can also be used as a test of personality (e.g., Catell- Luborsky Humor Test of Personality) (Morgan, 2001). Humor Styles Questionnaire (HSQ) (Martin et al., 2003) has four dimensions - two adaptive and two maladaptive styles of humor, relating to different uses or functions of humor in everyday life. It focuses on the interpersonal and intrapsychic functions relevant to psychosocial well-being and various aspects of mental health. Two of these dimensions are considered to be conducive to psychosocial well-being and the other two are less benign and potentially even deleterious to well-being. The two adaptive styles are affiliative and self-enhancing humor and the two maladaptive humor styles are aggressive and self-defeating humor. The affiliative humor style includes saying funny things, telling jokes, engaging in spontaneous way to amuse others to facilitate relationships, and to reduce interpersonal tensions (Martin et al., 2003; Campbell, Martin, Ward, 2008; Lefcourt, 2001; Kazarian, Martin, 2004). It has an interpersonal focus and according to Cann, Norman, Welbourne and Calhoun (2008), a relatively positive orientation to others, as reflected in an affiliative humor style, and it should be associated with a greater concern for others. Self-enhancing humor involves a generally humorous outlook on life and is consistent with the Freudian definition of humor as a healthy defense mechanism that allows one to avoid negative emotions while maintaining a realistic perspective on a potentially aversive situation, to maintain a humorous perspective even in the face of stress or adversity and to use humor as a coping strategy and emotion regulation (Martin et al., 2003; Kazarian, Martin, 2004). The self-enhancing humor style reflects high concern for self, reducing the conflict when protecting the self (Cann et al., 2008). Aggressive humor is the tendency to use humor for the purpose of criticizing or manipulating others, as in sarcasm, teasing and ridicule and relates to the tendency to express humor without regard for its potential impact on others (e.g., sexist or racist humor). This type of humor is directed at others to enhance positive feelings about oneself and includes compulsive expressions of humor in which one finds it difficult to resist the impulse to say funny things that are likely to hurt or alienate others (Martin et al., 2003; Kuiper, Leite, 2010; Kazarian, Martin, 2004; Saroglou, Scariot, 2002). Self-defeating humor involves humor that is excessively critical and ridiculing of oneself and attempts to amuse others by doing or saying funny things at one's own expense, and laughing along with others when being ridiculed or disparaged. Individuals with this humor style often allow themselves to be the "butt" of jokes in the hopes of gaining others' approval and acceptance, using it to enhance relationships with others but at the expense of positive feelings about oneself (Kuiper, Leite, 2010; Kazarian, Martin, 2004). It also involves the use of humor as a form of defensive denial, to hide one's true feelings from self and others (Kazarian, Martin, 2004; Cann et al., 2008).

In general, humor promotes positive feelings which is manifested in greater positive affect in response to both positive and negative life events (Martin et al., 1993; Martin, 2001). Similar to humor, mindfulness can also help us to accept the inevitable ups and 
downs of life rather than resist, to stop thinking about the past or future for more than a few seconds, experience the richness of the moments of our lives and to be receptive to not only our personal successes and joys, but also failures and sorrows (Siegel, 2010a). A basic definition of mindfulness is "moment-by-moment awareness" (Hanh, 1987). Becoming mindful involves observing where our attention goes minute by minute and noticing in which way our minds become distracted or preoccupied (Siegel, 2010a), freeing us from habitual styles of thinking and negative thought patterns, such as exaggerating the negative and discounting the positive, mind reading, being the eternal expert and the shouting and blaming. This process often occurs automatically (Stahl, Goldstein, 2010).

The study aims to find out 1) If mindfulness significantly predicts humor styles? 2) If the Five Factor Personality Traits significantly predict humor styles?

\section{METHOD}

\section{Participants}

A total of 502 undergraduate students, 300 (59.8\%) female and 202 (40.2\%) male, participated in this study voluntarily. The sample ranged in age from 18 to $26.36 .3 \%(\mathrm{n}=182)$ of the students were freshman, $35.7 \%(\mathrm{n}=$ 179) sophomore, $13.3 \%(n=67)$ third year and $14.7 \%(n=74)$ of the students were on their fourth year $(\mathrm{M}=20.93$ years, $\mathrm{SD}=1.80$ years).

\section{Measures}

Humor Styles Questionnaire (HSQ: Martin et al., 2003). The HSQ consists of a total of 32 self-report items assessing four different styles of humor, two of them are adaptive and two are maladaptive. Respondents indicate the degree to which they agree or disagree with each item using a seven-point Likert Scale. The four humor styles, with sample items are affiliative (e.g., 'I laugh and joke a lot with my close friends'); self-enhancing (e.g., 'Even when I'm by myself, I am often amused by the absurdities of life'); aggressive (e.g., 'If someone makes a mistake, I will often tease them about it'); and self-defeating (e.g., 'I will often get carried away in putting myself down if it makes my family or friends laugh'). HSQ was adapted into Turkish by Yerlikaya (2003), the Cronbach alpha coefficient scores of HSQ were found .74 for affiliative humor, .78 for self-enhancing humor, .69 for aggressive humor and .67 for self-defeating humor. The test-retest correlation coefficients of HSQ scale applied in two week intervals were, .88 for affiliative humor, .82 for selfenhancing humor, .85 for aggressive humor, and .85 for self-defeating humor. In this study, the reliability of the Cronbach alpha coefficients of HSQ dimensions was .76 for affiliative humor, .76 for self-enhancing, .54 for aggressive humor, and .71 for self-defeating humor. The test-repeat-test correlation coefficients of HSQ scale applied in two week intervals were .74 for affiliative humor, .81 for self-enhancing humor, .76 for aggressive humor, and .70 for self-defeating humor.

Adjective Based Personality Test (ABPT) was developed by Bacanl, Ilhan and Aslan (2009). ABPT is composed of five subdimensions (extroversion, emotional stability/neuroticism, agreeableness, conscientiousness). Principle Component Analysis has been conducted on the data collected from 285 
participants in order to determine the construct validity of ABPT. Analyses have showed that the Five Factor Model explains $52.63 \%$ of the variance in ABPT. The Sociotrophy Scale, Reaction to Conflicts Scale, Negative-Positive Emotion Scale, and Trait Anxiety Inventory have been used to determine the concurrent validity of ABPT. Test-retest was conducted with a two week interval and the Cronbach alpha internal consistency coefficients were calculated. The internal consistency coefficients of the dimensions of ABPT have changed in the range of .89 to .73 . As a result of the testretest analysis, Agreeableness was found to have the highest relationship ( $\mathrm{r}=.86$, $\mathrm{p}<.01$ ) and Openness to Experiences was found to have the lowest relationship $(\mathrm{r}=$ $.68, \mathrm{p}<.01)$.

Mindful Attention Awareness Scale (MAAS) developed by Brown and Ryan (2003) is a 15-item self-report instrument measuring an individual's attention to and awareness of present moment experiences in daily functioning. Participants respond to each item using a 6-point scale ranging from 1 (almost always) to 6 (almost never). Item responses for each participant are summed and averaged, yielding a total score of mindfulness ranging from 1 to 6 . Higher scores indicate higher levels of mindfulness. Examples of items include "I tend to walk quickly to get where I'm going without paying attention to what I experience along the way", "I do jobs or tasks automatically, without being aware of what I'm doing", and "I find myself preoccupied with the future or the past".

The Mindfulness Attention Awareness Scale was adapted into Turkish by Özyeşil, Arslan, Kesici and Deniz (2011) on a group of university students. The original scale and the translated form of the scale were applied to students from English language teaching department. A significant positive relationship was found between the scores of the Turkish and English forms of the MAAS $(r=.95, p<.001 ; r=.96, p<.001)$. The exploratory factor analysis (EFA) and the confirmatory factor analysis were applied to examine the factor validity of the scale. With respect to the results of the study, the scale is considered to be unidimensional. As a result of the item-total correlations of MAAS, all the items were calculated more than .40 . Factor loadings for each item of the scale changed between .484 and .805. Cronbach alpha internal consistency coefficient was calculated .80 and the test-retest correlation was .86. As a result of the analysis conducted for the criterion-related validity of the scale, we found positive correlations between MAAS and SCS (the self-compassion scale), significantly high and negative correlations with depression, anxiety and stress, as sub-dimensions of Depression, Anxiety and Stress Scale and a significantly high positive correlation with positive affect subscale and significantly high negative correlation with negative affect subscale of PANAS (the positive and negative affect scale).

\section{Procedure}

Consistent with the aim of the study, in order to analyze the data statistically, the Pearson Moments Multiple Correlation Technique was used to determine the correlation between humor styles and mindfulness with the Five Factor Personality Trait. The multiple regression analysis was used to determine if the Five Factor Personality Traits predicts the humor styles. 


\section{RESULTS}

As is shown in Table 1 there is a positive significant correlation between mindfulness and affiliative and self-enhancing humor styles, a negative significant correlation between mindfulness and aggressive and selfdefeating humor styles. The results indicating if mindfulness predicts humor styles are given in Table 2.

Mindfulness significantly predicts four subdimensions of humor styles. Mindfulness explains the $1.8 \%$ of the affiliative variance, $1 \%$ of the self-enhancing variance, $4.8 \%$ of the aggressive variance and $2.2 \%$ of the self-defeating variance.

The analysis indicating the correlation between the Five Factor Personality Traits and the humor styles are given in Table 3.

Findings indicating if the Five Factor Personality Traits predict the humor styles are given in Table 4. As is seen in the table, the Five Factor Personality Traits significantly predict the affiliative humor style as a whole $\left(\mathrm{R}=.400, \mathrm{R}^{2}=.160, \mathrm{~F}=18.854, \mathrm{p}<.001\right)$. The

Table 1. The correlations between Mindfulness and Humor Styles

\begin{tabular}{|l|c|c|c|c|}
\hline & Affiliative & Self Enhancing & Aggressive & Self Defeating \\
\hline Mindfulness & $.13^{* *}$ & $.10^{*}$ & $-.22^{* * *}$ & $-.15^{* *}$ \\
\hline
\end{tabular}

Table 2. Explanations of Humor Styles by Mindfulness

\begin{tabular}{|l|c|c|c|c|c|}
\hline $\begin{array}{l}\text { Dependent variable } \\
\text { (Humor Styles) }\end{array}$ & $\mathrm{R}$ & $\mathrm{R}^{2}$ & $\mathrm{~F}$ & $\beta$ & $\mathrm{t}$ \\
\hline Affiliative & .135 & .018 & $9.348^{* *}$ & .135 & $3.057^{* *}$ \\
\hline Self Enhancing & .101 & .010 & $5.158^{*}$ & .101 & $2.271^{*}$ \\
\hline Aggressive & .218 & .048 & $24.988^{* * *}$ & -.218 & $-4.999^{* * *}$ \\
\hline Self Defeating & .149 & .022 & $11.407^{* *}$ & -.149 & $-3.377^{* *}$ \\
\hline
\end{tabular}

Table 3. The correlation between the Five Factor Personality Traits and the Humor Styles

\begin{tabular}{|l|c|c|c|c|c|}
\hline & & Affiliative & $\begin{array}{c}\text { Self } \\
\text { Enhancing }\end{array}$ & Aggressive & $\begin{array}{c}\text { Self } \\
\text { Defeating }\end{array}$ \\
\hline $\begin{array}{l}\text { Emotional Instability / } \\
\text { Neuroticism }\end{array}$ & $\mathrm{r}$ & -.08 & $-.16^{* * *}$ & .08 & .07 \\
\hline Extraversion & $\mathrm{r}$ & $.35^{* * *}$ & $.25^{* * *}$ & $-.11^{*}$ & -.02 \\
\hline Openness to Experiences & $\mathrm{r}$ & $.32^{* * *}$ & $.28^{* * *}$ & $-.20^{* * *}$ & -.04 \\
\hline Agreeableness & $\mathrm{r}$ & $.12^{* *}$ & .05 & $-.35^{* * *}$ & -.08 \\
\hline Conscientiousness & $\mathrm{r}$ & $.10^{*}$ & .05 & $-.32^{* * *}$ & $-.14^{* *}$ \\
\hline
\end{tabular}

${ }^{*} \mathrm{p}<.05, * * \mathrm{p}<.01, * * * \mathrm{p}<.001$ 
Table 4. Explanations of Affiliative Humor Style by the Five Factor Personality Traits

\begin{tabular}{|c|c|c|c|c|c|}
\hline $\begin{array}{l}\text { Five Factor Personality } \\
\text { Traits }\end{array}$ & $\mathrm{R}$ & $\mathrm{R}^{2}$ & $\mathrm{~F}$ & $\beta$ & $\mathrm{t}$ \\
\hline $\begin{array}{l}\text { Emotional Instability / } \\
\text { Neuroticism }\end{array}$ & \multirow{5}{*}{.400} & \multirow{5}{*}{.160} & \multirow{5}{*}{$18.854 * * *$} & -.093 & $-2.237 *$ \\
\hline Extraversion & & & & .293 & $4.618 * * *$ \\
\hline Openness to Experiences & & & & .222 & $3.242 * *$ \\
\hline Agreeableness & & & & -.043 & -.749 \\
\hline Conscientiousness & & & & -.160 & $-2.726 * *$ \\
\hline
\end{tabular}

Five Factor Personality Traits (neuroticism, extraversion, openness to new experiences, agreeableness and conscientiousness) explain $16 \%$ of total variance in affiliative humor style. Considering the t-test results regarding the significance of regression coefficients, it is seen that the emotional instability/neuroticism $(\beta=-.093)$, extraversion $(\beta=$ $.293)$, openness to new experiences $(\beta=.222)$ and conscientiousness $(\beta=-.160)$ subdimensions predict affiliative humor style effectively. The agreeableness subdimension is not effective in predicting the affiliative humor style

The Five Factor Personality Traits significantly predict the self-enhancing humor style as a whole $\left(\mathrm{R}=.377, \mathrm{R}^{2}=.142, \mathrm{~F}=16.445\right.$, $\mathrm{p}<.001)$. The Five Factor Personality Traits (neuroticism, extraversion, openness to new experiences, agreeableness and conscientiousness) explain $14.2 \%$ of total variance in self-enhancing humor style. Considering the t-test results regarding the significance of regression coefficients, it is seen that emotional instability/neuroticism $(\beta=-.175)$, extraversion $(\beta=.161)$, openness to new experiences $(\beta=.309)$, agreeableness $(\beta=-.138)$ and conscientiousness $(\beta=-.122)$ subdimensions predict self-enhancing humor style effectively (Table 5).

The Five Factor Personality Traits significantly predict the aggressive humor style as a whole $\left(\mathrm{R}=.397, \mathrm{R}^{2}=.158, \mathrm{~F}=18.554, \mathrm{p}<\right.$ .001 ). The Five Factor Personality Traits (neu-

Table 5. Explanations of Self Enhancing Humor Style by Five Factor Personality Traits

\begin{tabular}{|c|c|c|c|c|c|}
\hline $\begin{array}{l}\text { Five Factor Personality } \\
\text { Traits }\end{array}$ & $\mathrm{R}$ & $\mathrm{R}^{2}$ & $\mathrm{~F}$ & $\beta$ & $\mathrm{t}$ \\
\hline $\begin{array}{l}\text { Emotional Instability / } \\
\text { Neuroticism }\end{array}$ & \multirow{5}{*}{.377} & \multirow{5}{*}{.142} & \multirow{5}{*}{$16.445 * * *$} & -.175 & $-4.170 * * *$ \\
\hline Extraversion & & & & .161 & $2.511 *$ \\
\hline Openness to Experiences & & & & .309 & $4.472 * * *$ \\
\hline Agreeableness & & & & -.138 & $-2.396 *$ \\
\hline Conscientiousness & & & & -.122 & $-2.058 *$ \\
\hline
\end{tabular}

$* \mathrm{p}<.05, * * * \mathrm{p}<.001$ 
Table 6. Explanations of Aggressive Humor Style by Five Factor Personality Traits

\begin{tabular}{|c|c|c|c|c|c|}
\hline $\begin{array}{l}\text { Five Factor Personality } \\
\text { Traits }\end{array}$ & $\mathrm{R}$ & $\mathrm{R}^{2}$ & $\mathrm{~F}$ & $\beta$ & $\mathrm{t}$ \\
\hline $\begin{array}{l}\text { Emotional Instability / } \\
\text { Neuroticism }\end{array}$ & \multirow{5}{*}{.397} & \multirow{5}{*}{.158} & \multirow{5}{*}{$18.554 * * *$} & .074 & 1.777 \\
\hline Extraversion & & & & .153 & $2.403^{*}$ \\
\hline Openness to Experiences & & & & -.031 & -.456 \\
\hline Agreeableness & & & & -.253 & $-4.452 * * *$ \\
\hline Conscientiousness & & & & -.228 & $-3.887 * * *$ \\
\hline
\end{tabular}

$* \mathrm{p}<.05, * * * \mathrm{p}<.001$

roticism, extraversion, openness to new experiences, agreeableness and conscientiousness) explain $15.8 \%$ of total variance in aggressive humor style. Considering the t-test results regarding the significance of regression coefficients, it is seen that the extraversion $(\beta=.153)$, agreeableness $(\beta=-.253)$ and conscientiousness $(\beta=-.228)$ subdimensions predict aggressive humor style effectively. However, the emotional instability/ neuroticism and openness to new experiences subdimensions are not effective in predicting the affiliative humor style (Table 6).

As is seen in Table 7, the Five Factor Personality Trait significantly predicts the self- defeating humor style as a whole $(\mathrm{R}=.174$, $\left.\mathrm{R}^{2}=.030, \mathrm{~F}=3.083, \mathrm{p}<.01\right)$. The Five Factor Personality Trait (neuroticism, extraversion, openness to new experiences, agreeableness and conscientiousness) explains 3\% of total variance in self-defeating humor style. Considering the t-test results regarding the significance of regression coefficients, it is seen that the conscientiousness $(\beta=-.195)$ subdimension predicts self-defeating humor style effectively. However, the emotional instability/neuroticism, extraversion, openness to new experiences and agreeableness sub dimensions do not effectively predict the selfdefeating humor style.

Table 7. Explanations of Self Defeating Humor Style by Five Factor Personality Traits

\begin{tabular}{|c|c|c|c|c|c|}
\hline $\begin{array}{l}\text { Five Factor Personality } \\
\text { Traits }\end{array}$ & $\mathrm{R}$ & $\mathrm{R}^{2}$ & $\mathrm{~F}$ & $\beta$ & $\mathrm{t}$ \\
\hline $\begin{array}{l}\text { Emotional Instability / } \\
\text { Neuroticism }\end{array}$ & \multirow{5}{*}{.174} & \multirow{5}{*}{.030} & \multirow{5}{*}{$3.083 * *$} & .086 & 1.924 \\
\hline Extraversion & & & & .049 & .722 \\
\hline Openness to Experiences & & & & .031 & .418 \\
\hline Agreeableness & & & & .012 & .195 \\
\hline Conscientiousness & & & & -.195 & $-3.099 * *$ \\
\hline
\end{tabular}

$* * \mathrm{p}<.01$ 


\section{DISCUSSION}

This study aimed to analyze the correlations between mindfulness and humor styles and the Five Factor Personality Traits. In addition, it is conducted to determine if mindfulness and the Five Factor Personality Traits predict the humor styles.

\section{Mindfulness and Humor Styles}

The results of the study show that there are positive significant correlations between mindfulness and humor styles. Humor Styles Questionnaire (HSQ) (Martin et al., 2003) has four dimensions - two adaptive and two maladaptive styles of humor - relating to different uses or functions of humor in everyday life which focus on the interpersonal and intrapsychic functions relevant to psychosocial well-being and various aspects of mental health.

There is a negative significant correlation between mindfulness and the two maladaptive humor styles; aggressive and self-defeating humor styles and significant positive correlations between affiliative and selfenhancing humor styles. Mindfulness significantly predicts four subdimensions of humor styles. The most effective explanation of mindfulness is in terms of aggressive humor style. Two of these dimensions, affiliative and self-enhancing humor styles are considered to be conducive to psychosocial well-being and the other two are less benign and potentially even deleterious to well-being. Mindfulness appears to enhance general well-being (Brown, Ryan, 2003) and it is related to healthy behavior, as it involves being aware of the purpose and, nonjudgmentally, of what is happening at the present moment in an accepting way (Kabat-Zinn, 2009; Shapiro, Carlson, 2009; Germer, Siegel, Fulton, 2005; Germer, 2009). Furthermore, being mindful entails the conscientious, contemplative and creative aspects of consciousness (Siegel, 2010b). The fact that mindfulness and adaptive humor styles are positively correlated might be due to both of them appearing to be positively associated with well-being and negatively associated with negative affectivity.

Mindfulness is a conscious awareness of one's whole self and other people and the context in which we live, being aware, awake and attending to the world around us. Having conscious awareness may lead mindful people to create powerful, positive relationships. Higher levels of mindfulness are associated with greater relationship satisfaction, significantly more positive affect, less negative affect and greater life satisfaction (Brown, Ryan, 2003; Brown, Ryan, Cresswell, 2007).

In the affiliative humor style, by amusing others we facilitate relationships and reduce tensions. The affiliative humor style has an interpersonal focus and relatively positive orientation to others (Cann et al., 2008). It is associated with greater concern for others, so that sense of humor may help to establish close relationships with others, enhancing social support (Lefcourt, 2001). According to Kuiper and Mchale (2009), positive view of self and the others facilitates greater use of affiliative humor, which in turn, provides more exposure to positive social interactions. Individuals with a greater sense of humor may be better able to cope with stress. Related to the view of humor as a coping mechanism, humor contributes to psychological health and coping with stress by enhancing social support (Martin, 2003; Kazarian, Mar- 
tin, 2004). Decreased use of self-enhancing and affiliative humor styles has been associated with increased depressive symptoms (Freewen et al., 2008).

Mindfulness involves accepting our moment to moment experience rather than engaging in mental commentaries and interpretations about what is happening now (Flowers, 2009). These kinds of thoughts help us loosen our painful preoccupation with the "self" (Siegel, 2010a), which might result in negative affectivity such as stress, anxiety and depression. According to a number of studies, mindfulness was related to lower neuroticism, anxiety, depression, negative affectivity and unpleasant affect (Brown, Ryan, 2003; Brown et al., 2007; Huffziger, Kuehner, 2009). Aggressive humor style, as mentioned before, has negative correlation with mindfulness and the most effective explanation of mindfulness involves the aggressive humor style (4.8\%). Aggressive humor includes saying funny things that are likely to hurt or alienate others (Kuiper, Leite, 2010; Saroglou, Scariot, 2002) and it is typically unrelated to well-being. Self-defeating humor style is used as a form of defensive denial by amusing others (Martin et al., 2003) and higher levels of self-defeating humor are associated with the opposite pattern of wellbeing, increased depression and reduced well-being.

\section{Five Factor Personality Traits and Humor Styles}

The other aim of the study was to find if the Five Factor Personality Traits significantly predict humor styles. The results of the study show that the Five Factor Personality Traits (neuroticism, extraversion, openness to new experiences, agreeableness and conscientiousness) explain $16 \%$ of total variance in affiliative humor style, $14.2 \%$ of total variance in self-enhancing humor style, $15.8 \%$ of total variance in aggressive humor style, $3 \%$ of total variance in self-defeating humor style.

Affiliative humor style is an essentially non-hostile, tolerant use of humor that is affirming of the self and others and enhances interpersonal attraction. It is expected to be positively related to extraversion, self-esteem, cheerfulness, intimacy, relationship satisfaction and positive emotions (Martin et al., 2003). The results of the study are consistent with the past research (Vernon et al., 2008; Greven et al., 2008; Martin, 2003; Saroglu, Scariot, 2002; Thorson et al., 1997) and both afilliative and self-enhancing humor styles positively correlated with Extraversion, which is positively related to social support, well-being and relationship satisfaction. Adopting more adaptive attitudes and behaviors might reduce the use of negative humor styles when interacting with others. Agreeableness and openness to new experiences are associated with greater flexibility and negatively correlated with neuroticism. Neurotic individuals generally tend to experience negative effect and are less likely to use self-enhancing humor, which had been found to have a positive impact on psychological health. Self-enhancing humor style is also positively correlated with cheerfulness, self-esteem, optimism, psychological well-being, and satisfaction with social support, and negatively related to depression, anxiety, and bad mood (Martin et al., 2003). The two adaptive dimensions of humor are strong indicators of a healthy personality and are closely tied to other positive affections. Another study (Greven et al., 2008) on determinants of general health in 
students, found that the effect of extraversion and openness on general health was found to be partially mediated by affiliative humor and self-enhancing humor was found to partially mediate the relations between neuroticism and general health. Individuals using positive styles of humor can be described as positive towards oneself and others, low in anxiety and well-balanced (Galloway, 2010).

The aggressive and self-defeating humor correlated positively with neuroticism, characterized by a strong inclination to negative moods such as depression, anxiety and anger. Self-defeating humor is seen as potentially detrimental to well-being when used excessively, since it involves denigration of the self and repression of one's own emotional needs (Martin et al., 2003). It can also be seen as self-criticizing to gain the approval or acceptance of others and it might be a form of defensive mechanism which might stem from the natural desire not to be rejected or judged by others, so you judge and criticize yourself before someone else. An aggressive humor style is also associated with lower levels of concern for others and poorer interpersonal relationships. These two maladaptive humor styles are both negatively correlated with conscientiousness, openness to new experiences and agreeableness. Individuals using negative styles of humor can be described as being negative towards themselves and others as well as not being open to new experiences (Galloway, 2010).

In conclusion, it appears that there are significant relationships between the personality traits mindfulness and humor. There are not many studies on mindfulness and humor and further research should be conducted in order to determine if mindfulness based therapies could have contributions to the subject of using adaptive humor styles when faced with hard times in life.

Received March 23, 2012

\section{REFERENCES}

BACANLI, H., İLHAN, T., ASLAN, S., 2009, Beş faktör kuramına dayalı bir kişilik ölçeğinin geliştirilmesi: Sıfatlara Dayalı Kişilik Testi (SDKT). Türk Eğitim Bilimleri Dergisi, 7, 2, 261-279.

BROWN, K.W., RYAN, R.M., 2003, The benefits of being present: Mindfulness and its role in psychological well-being. Journal of Personality and Social Psychology, 84, 822-848.

BROWN, K., RYAN, R., CRESSWELL, J., 2007, Mindfulness: Theoretical foundations and evidence for its salutary effects. Psychological Inquiry, 18, 4, 211-237.

BURGER, J.M., 2006, Personality. (Translator: İnan Deniz Erguvan Sarioğlu), İstanbul: Kaknüs publishing.

CAMPBELL, L., MARTIN, R.A., WARD, J.R., 2008, An observational study of humor use during a conflict discussion. Personal Relationships, 15, 1, 41-55.

CANN, A., NORMAN, M.A., WELBOURNE, J., CALHOUN, L.G., 2008, Attachment styles, conflict styles and humor styles: Interrelationships and associations with relationship satisfaction. European Journal of Personality, 22, 131-146.

CARVER, C.S., SCHEIER, M.F., 2000, Perspectives on personality (4th ed.) Boston: Allyn and Bacon.

CHAMORRO-PREMUZIC, T., 2008, Personality and individual differences. Oxford.: Blackwell Publishing.

COOPER, C., 2002, Individual differences. NewYork: Oxford University Press.

COSTA, P.T., MCCRAE, R.R., 1992, Revised $N E O$ Personality Inventory (NEO-PI-R) and NEO Five-Factor Inventory (NEO-FFI) professional manual. Odessa, FL: Psychological Assessment Resources.

COSTA, P.T., Jr., MCCRAE, R.R., 1985, The NEO Personality Inventory manual. Odessa, FL: Psychological Assessment Resources.

FLOWERS, S., 2009, The mindful path through shyness. Oakland: New Harbinger Publications. 
FREEWEN, P.A., BRINKER, J., MARTIN, R.A., DOZOIS, D.J.A., 2008, Humor styles and personality-vulnerability to depression. Humor, 21, 2, 179 195.

FUNDER, D.C., 1997, The Personality Puzzle. New York: W.W. Norton \& Company.

GALLOWAY, G., 2010, Individual differences in personal humor styles: Identification of prominent patterns and their associates. Personality and Individual Differences, 48, 563-567.

GERMER, C.K., 2009, The mindful path to selfcompassion: Freeing yourself from destructive thoughts and emotions. Hove: Routledge.

GERMER, C.K., SIEGEL, R., FULTON, P., (Eds.)., 2005, Mindfulness and psychotherapy. New York: Guilford Press.

GREVEN, C., CHAMORRO-PREMUZIC, T., ARTECHE, A., FURNHAM, A., 2008, A hierarchical integration of dispositional determinants of general health in students: The big five, trait emotional intelligence and humor styles. Personality and Individual differences, 44, 1562-1573.

HANH, T.N., 1987, The miracle of mindfulness: An introduction to the practice of meditation. Boston: Beacon Press

HUFFZIGGER, S., KUEHNER, C., 2009, Rumination, distraction and mindful self-focus in depressed patients. Behaviour Resarch and Therapy, 47, 3, 224-230.

JOSE, H., PARREIRA, P., THORSON, J.A., ALLWARDT, D., 2007, Multidimensional aspects of the sense of humor: A psychometric study of the MSHS on the Portuguese population. North American Journal of Psychology, 9, 595-610.

KABAT-ZINN, J., 2009, Full catastrophe living: Using the wisdom of your mind and body to face stress, pain, and illness. New York: Delacorte.

KAZARIAN, S.S., MARTIN, R.A., 2004, Humor styles, personality, and well-being among Lebanese university students. European Journal of Personality, 18, 209-219.

KUIPER, N.A., LEITE, C., 2010, Personality impressions associated with four distinct humor styles. Scandinavian Journal of Psychology, 51, 115-122.

KUIPER, N.A., MCHALE, N., 2009, Humor styles as mediators between self-evaluative standards and psychological well-being. Journal of Psychology: Interdisciplinary and Applied, 143, 4, 359. 376 .

LEFCOURT, H.M., 2001, Humor: The psychology of living buoyantly. New York: Kluwer Academic Publishers.
MARTIN, R.A., 2003, Sense of humor. In: S.J. Lopez, C.R. Snyder (Eds.), Positive psychological assessment: A handbook of models and measures (pp. 313-326). Washington, DC: American Psychological Association.

MARTIN, R.A., 2001, Humor, laughter and physical health: Methodological issues and research findings. Psychological Bulletin, 127, 504-519.

MARTIN, R.A., KUIPER, N.A., OLINGER, L.J., DANCE, K.A., 1993, Humor, coping with stress, self-concept, and psychological well-being. Humor: International Journal of Humor Research, 6, 89104.

MARTIN, R.A., PUHLIK-DORIS, P., LARSEN, G., GRAY, J., WEIR, K., 2003, Individual differences in uses of humor and their relation to psychological well-being: Development of the Humor Styles Questionnaire. Journal of Research in Personality, 37, 48-75.

MCCRAE, R.R., COSTA, P.T., Jr., 1987, Validation of the five-factor model of personality across instruments and observers. Journal of Personality and Social Psychology, 52, 1, 81-90.

MCCRAE, R.R, JOHN, O., 1992, An introduction to the five-factor model and its applications. Journal of Personality, 60, 2, 174-214.

Merriam-Webster's Collegiate Dictionary (10th ed.), 1993, Springfield, MA: Merriam-Webster.

MORGAN, C.T., 2001, Introduction to Psychology. New York: McGraw-Hill Book Company, Inc.

NILSEN, A.P., NILSEN, D.L.F., 2000, Encyclopedia of 20th-Century American Humor. Phoenix: Oryx Press.

ÖZYESIL, Z., ARSLAN, C., KESICI, S.., DENIZ, M.E., 2011, Adaptation of Mindful Attention and Awareness Scale into Turkish. Education \& Science, 36, 160, 224-235.

PERVIN, A.L., 1993, Personality (theory and research). New York: John Wiley \& Sons, Inc.

RUCH, W., CARRELL, A., 1998, Trait cheerfulness and the sense of humor. Personality and Individual Differences, 24, 551-558.

SAROGLOU, V., SCARIOT, C., 2002, Humor Styles Questionnaire: Personality and educational correlates in Belgian high school and college students. European Journal of Personality, 16, 43-54.

SHAPIRO, S.L., CARLSON, L.E., 2009, The art and science of mindfulness: Integrating mindfulness into psychology and the helping professions. Washington, DC: American Psychological Association Publications.

SHAVER, P.R., BRENNAN, A.K., 1992, Attachment styles and the big five personality traits: Their 
connections with each other and with romantic relationship outcomes. Personality and Social Psychology Bulletin, 18, 5, 536-545.

SIEGEL, J.D., 2010a, The mindful therapist. New York: W.W. Norton \& Company, Inc.

SIEGEL, R.D., 2010b, The mindfulness solution. Everyday practices for everyday problems. New York: The Guilford Press.

STAHL, B., GOLDSTEIN, E., 2010, A mindfulness-based stress reduction workbook. Oakland: New Harbinger Publications.

THORSON, J.A., POWELL, F.C., SARMANYSCHULlER, I., HAMPES, W., 1997, Psychologi- cal health and sense of humor. Journal of Clinical Psychology, 53, 605-619.

VERNON, P.A., MARTIN, R.A., SCHERMER, J.A., MACKIE, A., 2008, A behavioral genetic investigation of humor styles and their correlations with the Big-5 personality dimensions. Personality and Individual Differences, 44, 1116 1125.

YERLIKAYA, E., 2003, A study on the adaptation of Humor Styles Questionnaire. Unpublished Master Thesis, Cukurova University Institute of Social Sciences, Adana.

\title{
VŠÍMAVOSŤ A OSOBNOSTNÉ CHARAKTERISTIKY BIG FIVE AKO PREDIKTORY HUMORU
}

\author{
Z. Özyesil, M. Engin De niz, S. Kes i c i
}

Súhrn: Zámerom štúdie bolo určit', či sú všímavost' a osobnostné charakteristiky Big Five signifikantnými prediktormi humoru. Výskumná vzorka pozostávala z 502 vysokoškolákov, 300 (59,8\%) žien a $202(40,2 \%)$ mužov. Na zber dát sme použili Humor Styles Questionnaire (HSQ), Adjective Based Personality Test (ABPT) a Mindful Attention Awareness Scale (MAAS). Pri štatistickej analýze sme použili Pearsonovu koreláciu a viacnásobnú regresnú analýzu. Zistenia ukazujú, že všímavost' a osobnostné charakteristiky Big Five sú signifikantnými prediktormi subdimenzií štýlov humoru. 